\title{
Cutaneous mastocytosis: clinical, dermoscopic and pathological features
}

\author{
Arvind Kumar, ${ }^{1}$ Naveen Kumar Kansal $\quad$ (1) , ${ }^{2}$ Ramesh Pratap Anuragi ${ }^{2}$
}

${ }^{1}$ Pathology, All India Institute of Medical Sciences, Rishikesh, India

${ }^{2}$ Dermatology and Venereology, All India Institute of Medical Sciences, Rishikesh, India

\section{Correspondence to}

Dr Naveen Kumar Kansal; kansalnaveen@gmail.com

Accepted 18 November 2020

\section{DESCRIPTION}

A 1-and-a-half-year-old boy was brought by his parents with intermittently itchy, round to oval, yellowish to skin-coloured maculopapules on the trunk for the last 1 year. The lesions were about $0.5 \times 1 \mathrm{~cm}$ in size and were present on the chest, abdomen and back (figure 1). Stroking a lesion with a blunt object produced faint perilesional erythema with urtication (Darier's sign). There were no systemic reports. Clinical differential diagnoses of cutaneous mastocytosis (multiple mastocytomas) and juvenile xanthogranuloma were considered. Dermoscopy of a lesion revealed

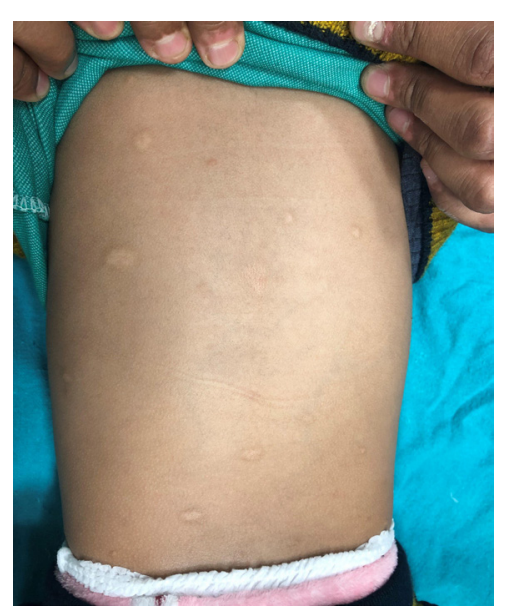

Figure 1 Round to oval, yellowish to skin-coloured lesions on the chest and abdomen.

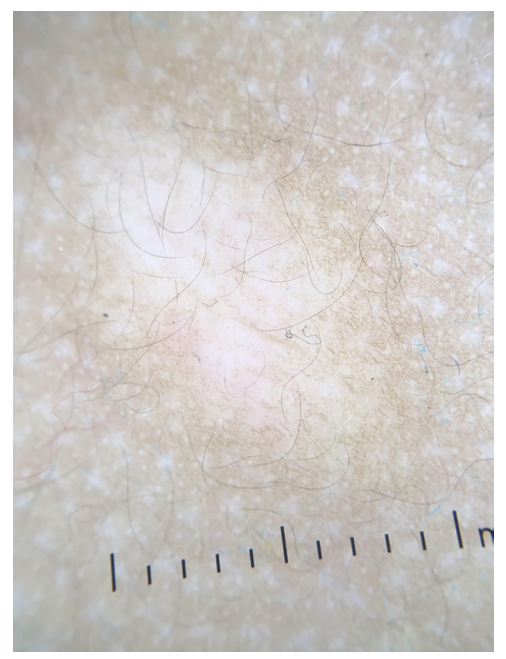

Figure 2 Dermoscopy. Central whitish area surrounded by a reticulate light brown rim on a yellowish background.

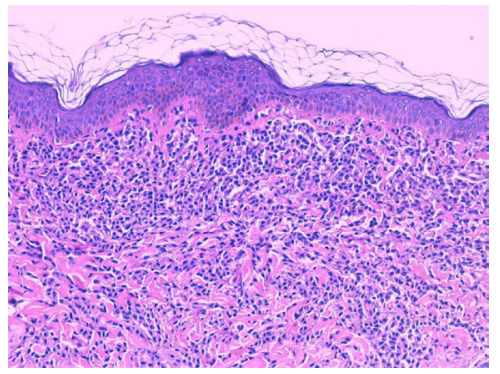

Figure 3 Pathology. Diffuse infiltration of the superficial epidermis by mastocytes (H\&E stain, original magnification, $\times 40$ ).

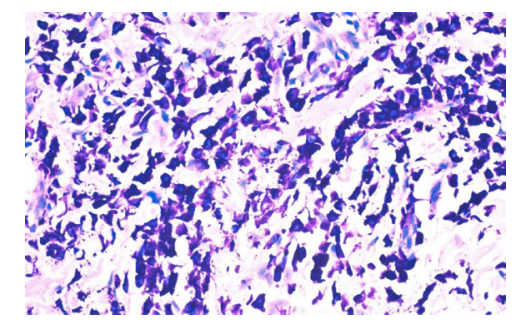

Figure 4 Giemsa stain demonstrates metachromatic mast cell granules (original magnification, $\times 100$ ).

a central whitish area surrounded by a reticulate light brown rim on a yellowish background (figure 2). A biopsy was taken for pathological examination, which revealed orthokeratotic epidermis with basal layer melanisation and diffuse infiltration by mastocytes in the superficial epidermis (figure 3). A Giemsa stain demonstrated metachromatic mast cell granules (figure 4). Therefore, based on clinical and dermoscopic features and pathological findings, a diagnosis of cutaneous mastocytosis (multiple mastocytomas) was made. ${ }^{12}$ The patient was started on $\mathrm{H}_{1}$

\section{Learning points}

- Cutaneous mastocytosis typically presents within the first few months of birth but a later onset is not uncommon. The lesions may urticate on stroking (Darier's sign).

- Dermoscopic features in cutaneous lesions of mastocytosis include a light brown rim, pigment network and yellow-orange blot.

- Pathological examination shows diffuse infiltration by mastocytes in the upper epidermis, which demonstrates metachromatic granules. 
antihistamines (syrup cetirizine $5 \mathrm{mg} / 5 \mathrm{~mL}$, half teaspoonful at bedtime) which led to symptomatic improvement. The patient is on regular follow-up.

Contributors AK: concept, design, literature search, manuscript preparation and review. NKK: concept, design, literature search, manuscript preparation, review and guarantor. RPA: concept, design, manuscript preparation, review and guarantor.

Funding The authors have not declared a specific grant for this research from any funding agency in the public, commercial or not-for-profit sectors.

Competing interests None declared.
Patient consent for publication Parental/guardian consent obtained.

Provenance and peer review Not commissioned; externally peer reviewed.

\section{ORCID iD}

Naveen Kumar Kansal http://orcid.org/0000-0001-9214-3137

\section{REFERENCES}

1 Grattan CEH, Radia DH, et al. Mastocytosis. In: Griffiths C, Barker J, Bleiker T, et al, eds. Rook's Textbook of Dermatology. 9th edn. Oxford: John Wiley \& Sons, 2016: 46.1-46.10.

2 Errichetti E, Stinco G. Dermoscopy in general dermatology: a practical overview. Dermatol Ther (Heidelb) 2016:6:471-507.

Copyright 2020 BMJ Publishing Group. All rights reserved. For permission to reuse any of this content visit

https://www.bmj.com/company/products-services/rights-and-licensing/permissions/

BMJ Case Report Fellows may re-use this article for personal use and teaching without any further permission.

Become a Fellow of BMJ Case Reports today and you can:

- Submit as many cases as you like

- Enjoy fast sympathetic peer review and rapid publication of accepted articles

- Access all the published articles

Re-use any of the published material for personal use and teaching without further permission

Customer Service

If you have any further queries about your subscription, please contact our customer services team on +44 (0) 2071111105 or via email at support@bmj.com.

Visit casereports.bmj.com for more articles like this and to become a Fellow 